https://doi.org/10.7250/scee.2021.0001

\title{
HOW DIGITAL ARE ALBANIAN ENTERPRISES: A MICROECONOMIC ANALYSES
}

\author{
Ermira KALAJ ${ }^{1}$, Flora MERKO² \\ ${ }^{1}$ University "Luigj Gurakuqi”, Shkoder, Albania \\ ${ }^{2}$ University “Aleksandër Moisiu”, Durrës, Albania \\ Corresponding authore-mail: ermira.kalaj@unishk.edu.al
}

\begin{abstract}
This paper focuses on the analyses of the digitalization of enterprises and its performance impact in Albania. Using data from 2019 Enterprise Surveys (ES) we try to give answer questions related to digitalization that characterize Albanian enterprises. The survey was a shared project of the European Bank for Reconstruction and Development (EBRD), the European Investment Bank (EIB), and the World Bank Group (WBG). The data are collected in Albania between January and May 2019. The objective of the survey is to better understand firms`experience in the private sector. Collected data are based on firms' experiences and perceptions of the environment in which they operate. The paper uses these specific questions to study Internet adoption. ES questionnaires focus on the following questions: (1) Does the firm have a highspeed Internet connection on its premises? (2) Does the establishment have its website? The dependent variable is the performance of the firms measured in terms of sales growth and labor productivity, while the vector of independent variables is composed of enterprise characteristics such as firm size, ownership structure, legal status, region, etc. Moreover, dummy variables are used to capture access to formal banking services and gender ownership.
\end{abstract}

Keywords: Information, Firm Performance, Entrepreneurship, Digitalization

JEL Classification: L15, L25, L26, L86

\section{INTRODUCTION}

According to recent studies (Katz et al. 2012; Bertschek et al. 2013; Arvin \& Pradhan, 2014) broadband connectivity contributes; to productivity improvements by enabling the implementation of more efficient marketing, inventory management processes; in enhanced innovation by creating new customer applications and services; and in more efficient functional distribution of labor, access to inputs, and customers. Through their websites, enterprises can offer detailed information about their products and services, campaigns, organizations, customers' reviews, and financial statements.

Traditionally, enterprises in developing countries such as Albania have encountered higher barriers in connecting and in gain access to information from markets. The use of the internet (Clarke \& Wallsten, 2006; Clarke, 2008; Ferro, 2011) plays an important role in lowering communication costs and barriers to entering new markets. Empirical evidence shows that increased internet adoption contributes to total trade through websites that facilitate communication and trading relationships. 
Therefore, it is important to study the microeconomic relationship between an enterprise's internet use and economic performance.

\section{LITERATURE REVIEW}

Few studies investigate the role of digitalization in Albanian enterprises and its contribution to their economic performance. Research is mainly concentrated mainly in the tourism (Noti \& Tartaraj, 2016; Kordha, et al., 2019; Pano \& Gjika, 2020) and financial service sector (Tolica et al., 2015; Balla, 2020) and analyzing the level of ICT penetration rather than its contribution in firms' performance.

The study of Curraj (2017) on business digitalization in Albania shows that the size, age, and location of the enterprises affect performance and are related to business digitalization more than strategy. Moreover, the entrepreneurial characteristics of the owner impact the level of enterprise digitalization. His research gives evidence that there is growing interest in ICT, digitalization, BI, and KM, but innovation is still at low levels due to limited financial and human resources.

Abedini and Hani (2017) analyze challenges and strategies for reducing the barriers to the adoption of information and communication technology in Albanian enterprises. Their findings indicate a positive correlation between ICT and economic efficiency and the competitiveness of enterprises. Authors conclude that ICT impact is higher are marketing, communication, networks, and resources.

The tourism sector's entrepreneurship is positively affected by ICT use according to Bekteshi (2017). However, the massive use of ICT is not a reality because of the perceived high costs of hardware and software. The results of the paper show that innovation plays an important role in increasing competition in the tourism sector. Innovation deficiencies that are found in this sector, are related to inadequate ICT investments by enterprises.

An interesting study by Gosavi (2017) analyses the adoption of the Internet by female-owned firms in India. Using Enterprise Surveys for 2014 she found out that female-owned firms in the country were more likely to use the Internet than their male counterparts. Similarly, these firms were more likely to use websites to communicate with their clients. The adoption of the Internet by enterprises, in any case, leads to better performance of firms.

Enterprises from Ghana and Nigeria were studied (Karakara \& Osabuohien, 2020) to determine whether there are differences in how ICT adoption affects innovation. It was established that competition leads to innovation. ICT usage positively affects innovation of firms in both countries, but the effects are different.

Using the Enterprise Survey firm-level data in the three rounds (2002, 2005, and 2008) Gërguri et al. (2017) investigate the impact of (ICT) and innovation activities on firm performance. The Probit model results show a significant effect of some of the innovation activities determinants, which are under the theoretical literature. Empirical results indicate that larger firms in transition economies tend to carry out more innovation activities than smaller ones.

Further investigation is needed to better understand the level of digitalization of enterprises in Albania and how much this digitalization affects their performance. 


\section{DIGITALIZATION OF ENTERPRISES}

Digitalization plays an important role in all sectors of the economy and enterprises are not an exception. In 2020, the percentage of enterprises that use computers for work purposes with internet access is $98.2 \%$ of the total enterprises (see Fig.1.).

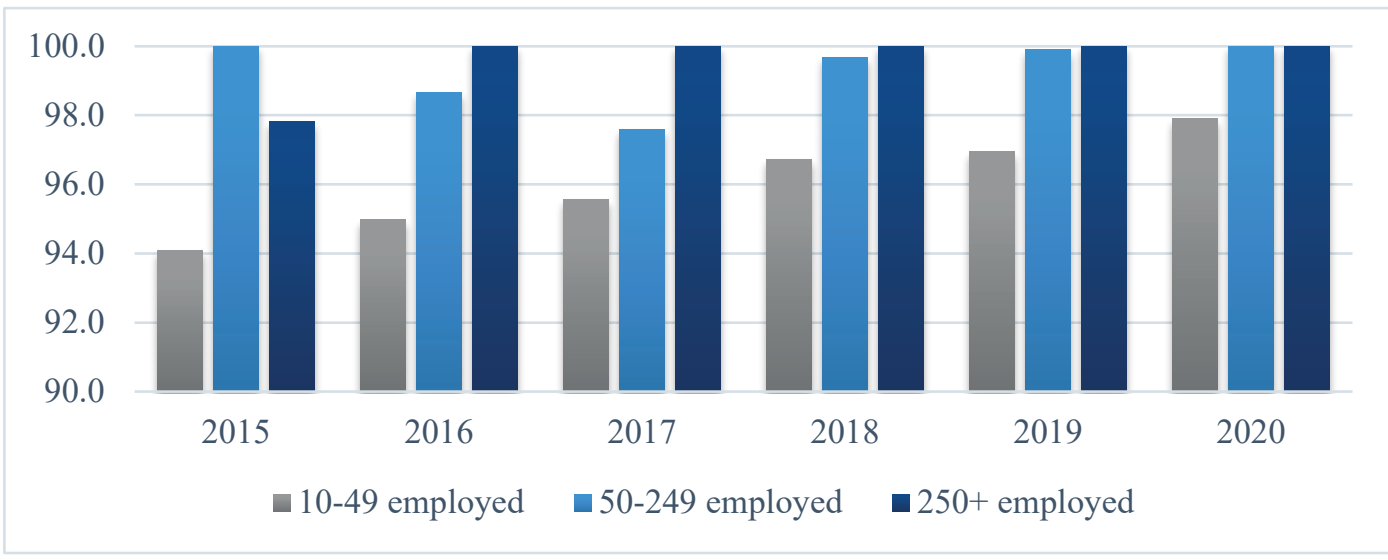

Fig. 1. Enterprises using computers $(10+)$

However, the percentage of employees using computers at their work remains low as Figure 2 shows.

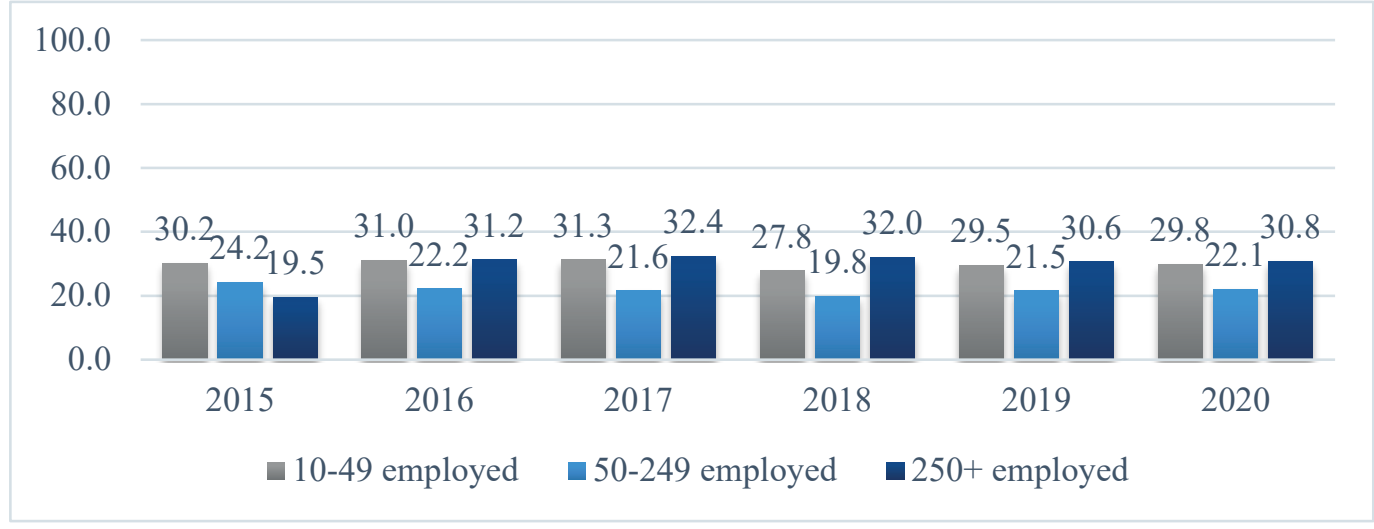

Fig. 2. Employees using computers at their work

According to INSTAT (2020), the share of employees using computers for work purposes is 27.2 percent from 26.8 percent that was in 2019. The lowest share of employees using the computer is respectively in manufacturing activities with 8.0 percent and construction activity with 16.2 percent. Computers are used to a greater level by employees of enterprises that perform in information and communication sectors by 75.5 percent, repair of computers and communication equipment by 73.7 percent, and professional, scientific, and technical activities by 64.9 percent as shown in Figure 3. 


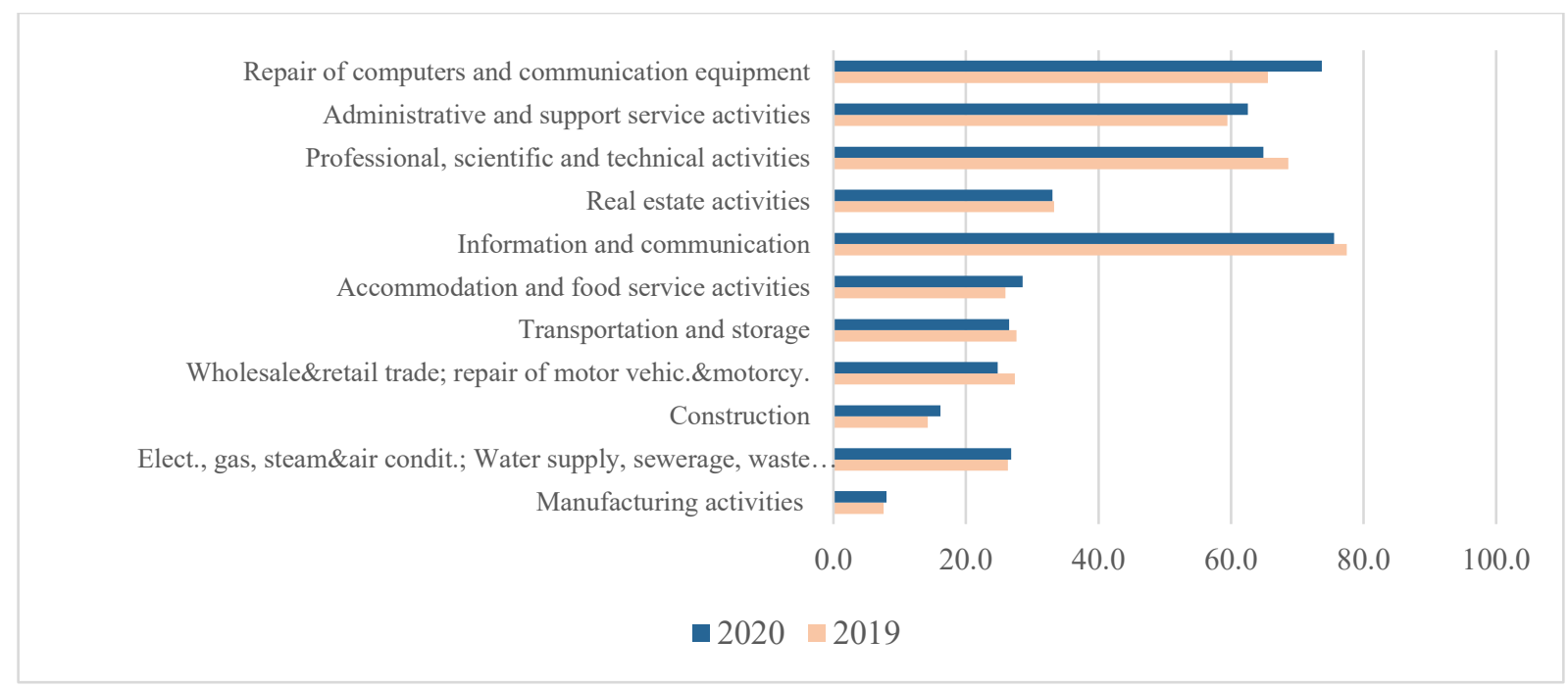

Fig. 3. Employees using computers at their work by sector

In 2020, as Figure 4 represents, 12.8 percent of enterprises have sold products/services via their website or dedicated applications, e-commerce marketplace websites and apps used by several enterprises for trading goods or services.

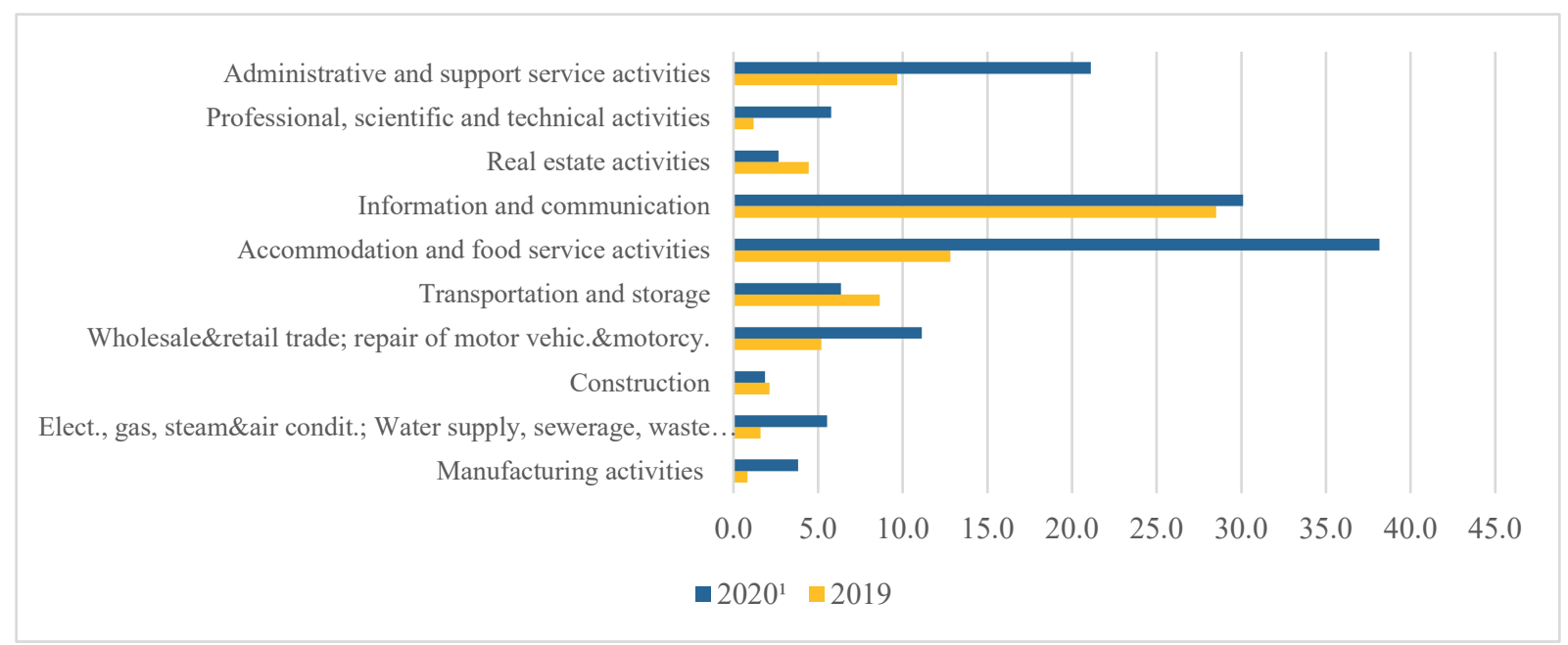

Fig. 4. Enterprises that did e-commerce sales $(10+)$ by sector

The highest share of electronic commerce is carried out by enterprises operating in the accommodation and food service activities by 38.2 percent, information and communication activities by 30.1 percent and administrative and support service activities by 21.1 percent. Still, the trend of online commerce is increasing, and further investigation is needed to better understand factors behind this tendency.

\section{EMPIRICAL RESULTS}

In this paper, the authors use data from 2019 Enterprise Surveys (ES) and focus on digitalization patterns that characterize Albanian enterprises. The survey was a shared project of the European Bank for Reconstruction and Development (EBRD), the European Investment Bank (EIB), and the World Bank Group (WBG), the data are collected in Albania between January and May 2019. The objective of the ES is to 
contribute to the understanding of what firms experience in the private sector. Collected data are based on firms' experiences and enterprises' perceptions of the environment in which they operate.

The data are stratified into three levels for Albania: industry, establishment size, and region. Industry stratification was completed as follows: Manufacturing combining all the relevant activities, Retail, and Other Services. Moreover, 2019 Albanian ES was based on the following size stratification: small (5 to 19 employees), medium (20 to 99 employees), and large (100 or more employees). Regional stratification was done across three regions: Northern Albania comprising Dibër, Durrës, Kukës, Lezhë, Shkodër, Central Albania comprising Tirana and Elbasan, and Southern Albania comprising Berat, Fier, Gjirokastër, Korçë, and Vlorë (WB, 2019).

According to the information related to the existence of the establishment's own website data are collected in graph 5. It is quite controversy that small enterprises respondents confirm the greater percentage of website presence. The fact that service enterprises have the major frequency of websites is consistent with the literature (Curraj, 2017; Gërguri et al., 2017); Balla, 2020).

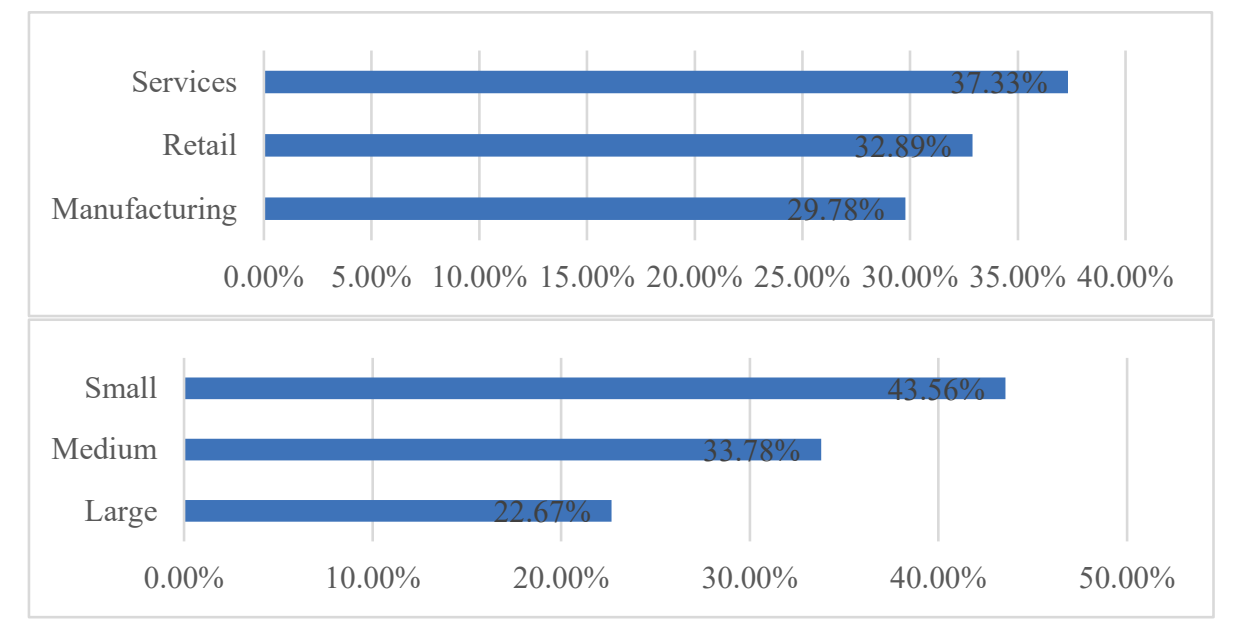

Fig. 5. Establishment has its own website by sector, by size

To investigate the impact of digitalization and give answer to our research questions we use the following model:

$$
Y_{i}=\beta_{0}+\beta_{1} \text { Internet }_{i}+\beta_{2} \text { Website }_{i}+\gamma X_{i}+\mu_{i}
$$

where:

$Y_{i}$ is one of the components of performance of the firms measured in terms of sales growth and labor productivity.

Internet and website are dummy variables to indicate the adoption of high-speed Internet or the usage of websites by firms,

$X_{i}$ is vector of variables including: the size, age, status, foreign ownership, location, exporter, and female-ownership etc.

The econometric results of the model are shown in table 1 . The first column describes coefficients related to the effect in sales growth of the selected independent variables. To compute the dependent variable sales growth, we follow Clarke et al. 
(2015) and Gosavi (2017) and use ES data from the years 2017. As mentioned earlier in the paper we include firm characteristics variables and ICT variables to check for digitalization and its impact.

Table 1. Empirical results on sales growth and labour productivity

\begin{tabular}{|c|c|c|}
\hline & $\begin{array}{l}\text { Sales growth } \\
\text { (1) }\end{array}$ & $\begin{array}{c}\text { Labour Productivity } \\
\text { (2) }\end{array}$ \\
\hline Has website & $\begin{array}{l}0.601 \\
(1.67)\end{array}$ & $\begin{array}{l}0.042^{* *} \\
(2.67)\end{array}$ \\
\hline Internet connection & $\begin{array}{c}1.31 \\
(0.01)\end{array}$ & $\begin{array}{l}0.128 \\
(0.42)\end{array}$ \\
\hline Formal banking & $\begin{array}{l}0.117 \\
(0.31) \\
\end{array}$ & $\begin{array}{c}-0.051^{* *} \\
(5.46)\end{array}$ \\
\hline Small & $\begin{array}{l}0.086 \\
(0.26) \\
\end{array}$ & $\begin{array}{l}0.048 \\
(0.14) \\
\end{array}$ \\
\hline Medium & $\begin{array}{l}0.118 \\
(0.36)\end{array}$ & $\begin{array}{l}0.293 \\
(0.85) \\
\end{array}$ \\
\hline Manufacturing & $\begin{array}{l}-0.453 \\
(-1.36)\end{array}$ & $\begin{array}{l}0.0225 \\
(0.07)\end{array}$ \\
\hline Retail & $\begin{array}{l}-0.182 \\
(-0.57)\end{array}$ & $\begin{array}{l}-0.123 \\
(-0.43)\end{array}$ \\
\hline Sole proprietorship & $\begin{array}{l}0.279 \\
(0.70) \\
\end{array}$ & $\begin{array}{l}0.643^{*} \\
(2.01) \\
\end{array}$ \\
\hline Foreign owned & $\begin{array}{l}0.913^{*} \\
(2.15)\end{array}$ & $\begin{array}{l}0.134 \\
(0.33)\end{array}$ \\
\hline Exporter & $\begin{array}{l}0.481^{* *} \\
(10.61)\end{array}$ & $\begin{array}{c}0.260^{* *} \\
(9.35)\end{array}$ \\
\hline Female owned & $\begin{array}{r}0.260 \\
(0.84)\end{array}$ & $\begin{array}{l}0.434 \\
(1.60)\end{array}$ \\
\hline \multicolumn{3}{|l|}{ cut1 } \\
\hline \multirow[t]{2}{*}{ cons } & -0.0193 & 0.239 \\
\hline & $(-0.06)$ & $(0.65)$ \\
\hline$R^{2}$ & 0.23 & 0.68 \\
\hline$N$ & 377 & 377 \\
\hline
\end{tabular}

$t$ statistics in parentheses

${ }^{*} p<0.05,{ }^{* *} p<0.01,{ }^{* * *} p<0.001$

According to the results shown in table 1 only few coefficients are statistically significant and further investigation is needed. Enterprises having websites exhibit higher labor productivity than others, and the result is statistically significant, but the magnitude is relatively low. The results are not statistically significant when it comes to sales growth.

Female ownership does not mean statistically higher sales growth or labor productivity. Nevertheless, coefficients have positive signs meaning that there is space for further analyses. These findings are like those of other gender studies in Albania (Kalaj and Merko, 2020). Interesting is the positive result for foreign and exporter enterprises. Enterprises that are involved in export activities are more likely to use both high-speed Internet and websites.

\section{CONCLUSION}

This study is concentrated on the analyses of the digitalization of Albanian enterprises. Digitalization is measured in this context by the adoption of high-speed 
Internet and the usage of firms' websites. To study this phenomenon, the paper used the World Bank's ES data set for 2019.

Empirical results show that digitalization affects enterprise performance only in part. The effect is positive and statistically significant when it comes to labor productivity. This is quite interesting meaning that employees using digital tools during operations become more productive. Nevertheless, this finding may be more related to the sector. If compared to other sectors, manufacturing-sector enterprises are less likely to use the technology than others.

This study offers an informative frame for the policy formulation on how to help enterprises in their way toward digitalization. Still, additional research is needed mainly by using data during the pandemic to investigate in what direction and how much lockdown periods affected the way enterprises behave in terms of ICT adoption.

\section{REFERENCES}

Abedini, L. V., \& Hani, R. Z. (2017). Challenges of ICT Approval in Small And Medium Enterprises in the Republic of Albania. UBT Proceedings, 43-48.

Arvin, M., \& Pradhan, R. (2014). Broadband penetration and economic growth nexus: Evidence from cross-country panel data. Journal of Applied Economics, 35(46), 4360-4369.

Balla, R. (2020). Digitalization of Financial Services in Albania Under Restricted Measures Covid-19. European Journal of Marketing and Economics, II(3), 17-31.

Bekteshi, L., \& Bekteshi, J. (2017). Use of ICT and development of tourism sector in Albania. European Scientific Journal, 13(25), 138-149.

Bertschek, I., Cerquera, D., \& Klein, G. J. (2013). More bits-more bucks? Measuring the impact of broadband internet on firm performance. Information Economics and Policy, III(25), 190-203.

Clarke, G. R., Qiang, C. Z., \& Xu, L. C. (2015). The Internet as a general-purpose technology: Firmlevel evidence from around the world. Economics Letters, 135, 24-27.

Clarke, R. G. (2008). Has the Internet Increased Exports for Firms from Low and Middle-Income Countries? Information Economics and Policy, I(20), 16-37.

Clarke, R. G., \& Wallsten, S. J. (2006). Has the Internet Increased Trade? Developed and Developing Country Evidence. Economic Inquiry, III(44), 465-84.

Curraj, E. (2017). Business Digitalization in Albania: Where do SMEs Stand? European Journal of Economics and Business Studies, I(3), 148-152.

Ferro, E. (2011). Signaling and Technological Marketing Tools for Exporters. World Bank Policy Research Working Paper 5547, WB.

Gërguri-Rashiti, S., Ramadani, V., Abazi-Alili, H., Dana, L. P., \& \& Ratten, V. (2017). ICT, innovation and firm performance: the transition economies context. Thunderbird International Business Review, I(59), 93-102.

Gosavi, A. (2017). Use of the Internet and its impact on productivity and sales growth in female-owned firms: Evidence from India. Journal of Entrepreneurship, Management and Innovation, II(13), $155-178$.

INSTAT. (2020). Usage of Information and Communication Technologies in Enterprises. Republika e Shqipërisë: Instituti i Statistikave.

Kalaj, E., \& Merko, F. (2020). Analyses of Financial Obstacles Facing SME-S: Evidence from Albania. Scientific Papers, I(43), 117-121.

Karakara, A. A., \& Osabuohien, E. (2020). ICT adoption, competition and innovation of informal firms in West Africa: a comparative study of Ghana and Nigeria. Journal of Enterprising Communities: People and Places in the Global Economy, 397-414.

Katz, R., Vaterlaus, S., Zenhausern, P., \& Suter, S. (2012). The impact of broadband on jobs and the German economy. Intereconomics, I(45), 26-34.

Kordha, E., Gorica, K., \& Sevrani, K. (2019). The Importance of Digitalization for Sustainable Cultural Heritage Sites in Albania. Cultural Sustainable Tourism, 91-97.

Noti, E., \& Tartaraj, A. (2016). E-commerce as an Added Value in the Tourism Services in Albania. Academic Journal of Interdisciplinary Studies, I(5), 324-329.

Pano, N., \& Gjika, I. (2020). Our Way Towards the Integration of Digital Technology. Journal of International Cooperation and Development, I(3), 19-25. 
Tolica, E. K., Sevrani, K., \& Gorica, K. (2015). Albanian Situation Related to the Factors for ICT Development. In Information Society Development through ICT Market Strategies, Springer, Cham, 67-83.

WB. (2019). Albania 2019 ES Implementation Report. Washington : World Bank.

\section{AUTHORS' SHORT BIOGRAPHY}

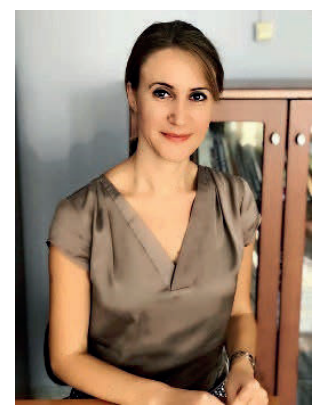

Ermira Kalaj is a Professor of Public Economics at the University of Shkodra. She received her Ph.D. degree in "Economics and Management" from the University of Trento, Italy, and her M.A in "Management of Development" from University of Turin, Italy. She is a holder of CERGE-EI Foundation Teaching Fellows Career Integration Fellowship, (2017-2020, 2020-2023).

Ermira Kalaj joined the University of Shkodra in 2015. She previously held faculty positions at the University of Durrës. She has served as Chair of the Economics Department at the University of Durrës from September 2009 to November 2015.

Her current research interests include public sector economics; the effects of immigration; income distribution; and econometric methods for program and policy evaluation.

E-mail: ermira.kalaj@unishk.edu.al

ORCID: https://orcid.org/0000-0003-4692-6055

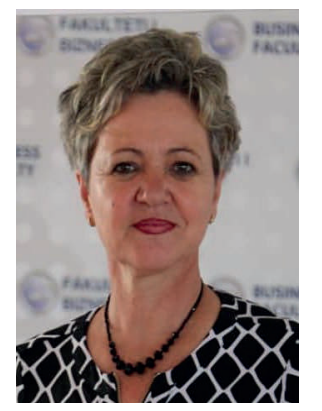

Flora Merko is a Professor of Economics at the Aleksander Moisiu University of Durres. She completed her higher studies at the Agricultural University of Tirana, Department of Economics in 1994 and Master of Science studies in 2003. She received her Ph.D. degree in February 2008 in "Economy and Agribusiness", and from December 2015 the title "Associate Professor". She is also the holder of the titles "Certified Public Accountant", and "Internal Auditor in the Public Sector", issued by the Ministry of Finance.

Assoc. Prof. Flora Merko joined the Aleksander Moisiu University of Durres in 2014. By May 2015 and on, she holds the position as Head of Economics Department in the Business Faculty of this University, and from June 2020, member of the Academic Senate of this University. For the last 15 years, she continues to give lessons as an invited lecture at the Agriculture University of Tirana, and the Aleksander Xhuvani University of Elbasan. Her scientific research is focused on taxation, good governance, environmental economics, labor market dynamics, economic policies in the function of sustainable economic growth, regional development, etc.

E-mail: floramerko@uamd.edu.al 